$\underline{\text { Review Articles }}$

\title{
Malaria and Hiv in Adults: when the Parasite Runs into the Virus
}

Emanuele Focà, Silvia Odolini, Nigritella Brianese and Giampiero Carosi

Institute for Infectious and Tropical Diseases, University of Brescia. Brescia, Italy

Correspondence to: Emanuele Focà, MD. Institute of Infectious and Tropical Diseases, University of Brescia, School of Medicine, P.le Spedali Civili, 125123 Brescia (Italy). Tel: +39.030.3995677; Fax: +39.030.303061. Email: emanuelefoca@gmail.com

Competing interests: The authors have declared that no competing interests exist.

Published: May 7, 2012

Received: March 28, 2012

Accepted: May 2, 2012

Citation: Mediterr J Hematol Infect Dis 2012, 4(1): e2012032, DOI: 10.4084/MJHID.2012.032

This article is available from: http://www.mjhid.org/article/view/10306

This is an Open Access article distributed under the terms of the Creative Commons Attribution License (http://creativecommons.org/licenses/by/2.0), which permits unrestricted use, distribution, and reproduction in any medium, provided the original work is properly cited.

Abstract. Malaria and HIV/AIDS are among the principal causes of morbidity and mortality worldwide, particularly in resource-limited settings such as sub-Saharan Africa. Despite the international community's efforts to reduce incidence and prevalence of these diseases, they remain a global public health problem. Clinical manifestations of malaria may be more severe in HIV infected patients, which have higher risks of severe malaria and malaria related death. Co-infected pregnant women, children and international travelers from non-malaria endemic countries are at higher risk of clinical complications. However, there is a paucity and conflicting data regarding malaria and HIV co-infection, particularly on how HIV infection can modify the response to antimalarial drugs and about drug-interactions between antiretroviral agents and artemisininbased combined regimens. Moreover, consulting HIV-infected international travelers and physicians specialized in HIV care and travel medicine should prescribe an adequate chemoprophylaxis in patients travelling towards malaria endemic areas and pay attention on interactions between antiretrovirals and antimalarial prophylaxis drugs in order to prevent clinical complications of this co-infection.

This review aims to evaluate the available international literature on malaria and HIV co-infection in adults providing a critical comprehensive review of nowadays knowledge.

Introduction. Malaria is one of the most important causes of morbidity and mortality in tropical regions, especially in sub-Saharan Africa and South-East Asia. ${ }^{1}$ The disease is caused by an infection sustained by a parasite of the genus Plasmodium; five species of Plasmodium ( $P$. falciparum, $P$. vivax, $P$. ovale, $P$. malariae and $P$. knowlesi) can infect human and among these species, $P$. falciparum infection may be fatal. $^{2}$
According to the World Malaria Report 2010, there were 225 million cases of malaria and an estimated 781 000 deaths in 2009. Most deaths occur among children living in Africa where a child dies every 45 seconds for malaria and this disease accounts for approximately $20 \%$ of all childhood deaths. ${ }^{2}$

Human Immunodeficiency Virus (HIV) is a retrovirus that can infect immune competent cells causing an impairment of host defense. After the 
introduction of Highly Active Antiretroviral Therapy (HAART) in 1996, the epidemiology of HIV infection has changed and clinical evolution turned a fatal disease in a treatable chronic infection with an improved quality of life and a reduction of morbidity and mortality. ${ }^{3}$ However, nowadays there are still alarming figures of HIV/AIDS infected people worldwide: in 2010 it was estimated that people living with HIV infection were 34 million, 2.7 million people became newly infected in the same year and AIDSrelated deaths were 1.8 million, including 250000 children. Two thirds of HIV infections were in subSaharan Africa. ${ }^{4}$ Therefore, there is a critical overlap between the two infections especially in sub-Saharan Africa resulting in particular concern for Public Health. The increasing number of people potentially coinfected makes this topic of particular interest in order to correctly understand and control both infections and their particular interactions. ${ }^{5}$

Clinical presentation of malaria in HIV-infected people, even if partially immune to Plasmodium, may be more severe and, although malaria is not the main cause of death among HIV-infected patients, ${ }^{6}$ in a systematic review of HIV-1 infection in Africa, malaria was identified as the third cause of HIV-related morbidity. ${ }^{7}$ This is more evident in special populations such as HIV-infected pregnant women, ${ }^{8}$ as well as in adults male and female with an severely impaired immune system ${ }^{9}$ and in HIV-infected travelers. ${ }^{10}$

Moreover, despite the importance of proper treatments against both infections, there is a lack of data regarding treatment issue: conflicting data are presented in literature about the effects of antimalarial drugs (for treatment and chemoprophylaxis) on antiretroviral agents and vice-versa and data about drug-interactions between antimalarial (especially artemisinin-based combinated treatment - ACT) and antiretroviral drugs are missing. ${ }^{11}$

Purpose of this article is to review the current knowledge on clinical tools of malaria and HIV coinfection in adults, focusing on pregnant women and international travellers, and to explore the interactions between antiretrovirals and antimalarial drugs, suggesting future research priorities.

Interactions Between Malaria and HIV Infection. Sub-Saharan Africa represents the region most heavily affected by both malaria and HIV. In this setting, the overlap of these two infections is common and it would be important to understand their interactions and their correct management in order to limit their clinical burden. $^{12}$

The influences between HIV and malaria are bidirectional and synergistic, ${ }^{5,13}$ and the negative effects of this co-infection, for the most part, seems to be due to immunological interactions: HIV replication impairs immune system and consequently malaria control ${ }^{14}$ on the other hand, malaria itself enhances HIV replication by cytokines release and T-cell activation. ${ }^{15}$

Looking at HIV-infection during malaria, it seems that HIV infection worsens the capability to control parasitaemia because of deterioration of immune responses to malaria parasites; several studies reported an association between HIV infection and higher levels of malaria parasitaemia. Whitworth et al. demonstrated that higher levels of parasitaemia were more frequently detected among HIV-positive patients compared to those mono-infected $(11.8 \%$ vs $6.3 \%, \mathrm{p}<0.0001)$, moreover they found an association between lower CD4+ T-cell count and higher levels of parasitaemia $(\mathrm{p}=0.0076)$, and lower CD4+ T-cell count and risk of clinical manifestations of malaria. ${ }^{14}$ French et al. confirmed this data finding that incidence rates of $P$. falciparum malarial fever were indirectly proportional to CD4+ T-cell count, ${ }^{16}$ while Patnaik and colleagues supported the relationship between CD4+ T cell count and malaria parasitaemia in HIV-seropositive subjects finding an adjusted hazard ratio of 1.8 for a first parasitaemia episode, and of 2.5 for a second parasitaemia episode. ${ }^{17}$

The intensity of malaria transmission and the population's level of acquired immunity may influence the clinical impact of malaria. Two major levels of malaria endemicity are described: i) areas of high (stable) malaria transmission, where most of adults have developed enough immunity that lead to poor clinical manifestations of malaria infection and where the reported incidence of malaria was $\geq 1 / 1000$ per year in $2009 ;{ }^{4}$ ii) areas of low (unstable) malaria transmission, where people have not acquired a significant level of immunity with consequent high level of clinical appearance of the infection. In these areas the transmission is more often seasonal and the reported incidence of malaria was $<1 / 1000$ population per year in 2009. ${ }^{4}$ Severe malaria and consequent deaths seem to be higher in unstable transmission areas, ${ }^{18}$ but some studies have demonstrated an increase in malaria incidence in regions of stable malaria transmission when it is associated with HIVinfection. ${ }^{14,16}$ Whitworth's study, previously mentioned, was conducted in malaria endemic regions in Uganda, and demonstrated that risk of clinical malaria was $4.0 \%$ among HIV-1-positive patients and $1.9 \%$ among HIV-negative patients $;{ }^{14}$ also French's trial was conducted among people from Uganda. However, some studies show conflicting data not describing an increase in severity of malaria from areas of stable transmission. Cohen et al. found a statistical significant correlation $(\mathrm{p}=0.003)$ between severe 
malaria and HIV infection among people nonimmune to malaria, instead this association was not found in semi-immune patients $(\mathrm{p}=0.284){ }^{9}$ Other studies ${ }^{19,20}$ concluded for the lack of association between HIV infection and malaria outcomes, but they suffer form some limitations: patients analysed were predominantly children ${ }^{19}$ or only children ${ }^{20}$ that, for their characteristic anti-parasite immunity are not comparable with adult population. ${ }^{16}$

HIV-positive patients with malaria presented higher incidence of anaemia, ${ }^{21}$ as demonstrated in a study in which co-infected patients showed lower haemoglobin levels compared to subjects with only malaria; ${ }^{22}$ in fact, both malaria and HIV may cause anaemia, as well as some drugs (e.g. zidovudine - AZT) used for HIV treatment. ${ }^{23}$

Looking now at the consequences of malaria infection on HIV disease progression, several studies showed an increased HIV-RNA replication in patients with malaria. Hoffman et al found 7-fold higher levels of HIV-1 RNA in patients with malaria than in those with only HIV infection $(p<0.0001)^{24}$ and another study showed that HIV-1 RNA concentrations were even 10-fold higher in co-infected patients in respect of HIV mono-infected patients. ${ }^{5}$ In a trial conducted in Malawi, Kublin and colleagues demonstrated that viral load returned at baseline levels only after 8-9 weeks of antimalarial therapy. ${ }^{25}$ Epidemiological implications of this aspect are that higher HIV-transmission rates are present in co-infected patients. ${ }^{26}$

Based on data presented, we suggest a strict monitoring of co-infected patients in order to improve the outcomes of these two infections, in particular for people most at risk of complications, such as pregnant women, in particular in stable malaria transmission areas where adults' parasitaemia values are often below threshold of detection.

Malaria and HIV Co-Infection in Pregnant Women. It is estimated that each year about 24 million pregnant women are infected by $P$. falciparum, especially in sub-Saharan Africa ${ }^{8}$ and about 1 million per year are co-infected with HIV. ${ }^{27}$ It is known that co-infected pregnant women are particularly at risk of complications due to these two infections; in fact, women during pregnancy are more likely susceptible to malaria disease than non-pregnant women, ${ }^{28}$ and a down regulation of the adaptive immune response was observed with a consequent enhanced placental invasion. ${ }^{29}$ High levels of parasitaemia and chronic parasite infection in placental blood can lead to consumption of nutritive blood substances, ${ }^{30}$ to a worsening of perinatal outcomes and to increased rates of maternal morbidity. ${ }^{31}$ In this context co-infection with HIV represents a further immune system impairment, which can be a concurrent cause of uneffectiveness in parasitaemia control. ${ }^{12}$

Consequences of this co-infection are described in both directions: HIV may promote more severe malaria clinical manifestations and, on the other hand, malaria can favours HIV RNA replication threatening antiretroviral treatment effectiveness. ${ }^{32}$

In co-infected pregnant women, all the adverse pregnancy outcomes are present. HIV impaired malaria outcomes inducing chronic parasitaemia, higher parasite densities and fever, reflecting in more severe clinical malaria manifestations. ${ }^{12,33}$ In a study conducted by ter Kuile and colleagues data from several works were summarized: the risk ratio $[R R]$ of malaria parasitaemia in co-infected women were 1.58 during pregnancy, 1.66 at the time of delivery and 1.66 in the placenta in respect of HIV-uninfected women. ${ }^{34}$ There is also an higher risk of postpartum maternal anaemia: Ayisi et al. found that the probability to manifest this clinical condition was more than twice higher in women co-infected than in HIV-uninfected women. ${ }^{35}$ Malaria and HIV infections were associated with several negative outcomes in newborns to coinfected mothers. Ticconi et al. demonstrated an association between co-infection and an increased risk of stillbirth $(\mathrm{OR}=4.74,95 \% \mathrm{CI}: 1.34-16.78)$ and preterm delivery $(\mathrm{OR}=4.10,95 \% \mathrm{CI}: 2.17-7.75)$. The two infections, instead, resulted independently associated with an increased risk of low birth weight (malaria: OR $=10.09,95 \%$ CI: 6.50-15.65; HIV: OR = 3.16, 95\% CI: $1.80-5.54)$ and foetal growth retardation (malaria: OR $=3.98,95 \%$ CI: 2.51-6.30; HIV: OR = 4.07, 95\% CI: 2.40-6.92) compared to HIV-uninfected women. ${ }^{36}$ Low birth weight (LBW) prevalence appear to be higher in co-infected women $(\mathrm{P}=0.001)$ compared to HIV mono-infected women $(\mathrm{p}=0.09)$ and malaria infected alone $(\mathrm{P}=0.006)$. In addition infant mortality seems to be higher in infants born to co-infected women. A study conducted in Malawi reported significantly higher mortality rates among children born to HIV-seropositive compared to HIVseronegative women, and in the multivariate model the risk of neonatal mortality was 4.5 greater in co-infected mother compared to mother with only placental malaria and 2.7-7.7 greater in HIV mono-infected mothers. ${ }^{37}$

As previously said, malaria promotes HIV RNA replication: a study showed that women had about 2fold increase in HIV-1-RNA both in peripheral and placental blood, with a consequent higher possibility of mother-to-child transmission of $\mathrm{HIV},{ }^{38}$ even if, at present, a clear association between placental malaria and an increase of mother-to-child transmission of HIV infection still remains uncertain. ${ }^{12}$

An appropriate control of both infections is a 
priority either for women and for their infants. The main recommendations are: a prompt HAART initiation in pregnant women as soon as the eligibility criteria are met, or an effective antiretroviral prophylaxis if criteria for initiating ART are not present, according to World Health Organization (WHO) specific guidelines. ${ }^{39}$ Therefore a proper prophylaxis with co-trimoxazole after the first trimester of pregnancy seems to prevent both opportunistic infections and malaria. ${ }^{34}$

Malaria in HIV-Infected International Travellers. According to the World Tourism Organization (WTO), an increasing number of international travellers has been reported, from 50 million/year after second World War to 980 million/year during $2011 .^{40}$ Approximately 80 million persons from industrialized nations travel to the tropical world each year. ${ }^{41}$ Imported malaria mostly occurs in tourists and migrants travelling to their origin countries to visit friends and relatives (VFR) ${ }^{42}$ but higher rates of malaria infection have been reported also among HIV-infected people. ${ }^{43}$

This is mainly due to the introduction of HAART and the improved quality of life allowed a steady increase of international travels, especially to tropical areas. ${ }^{44} \mathrm{~A}$ recent report showed that international travel among HIV-infected people was associated with poor adherence to antiretroviral therapy, risky sexual practices and risky exposure to travel-related diseases. ${ }^{45}$ Although any travel-related disease may have more severe clinical manifestations in HIV positive travellers compared to HIV-uninfected persons, malaria is certainly one of the most dangerous conditions; ${ }^{46}$ therefore HIV-infected patients should be more aware of the necessity for medical counsel prior to $\operatorname{travel}^{47,48}$ particularly to prevent malaria infection.

Several cases of imported malaria, as well severe cases with fatal outcome, have been reported; ${ }^{49,50,51,52}$ however clinical presentation is often similar to HIVnegative patients as recently reported in a retrospective study conducted in Spain. ${ }^{53}$ These data suggest that more caution should be taken during the pre-travel counselling.

WHO recommends a viro-immunological parameters check $(\mathrm{CD} 4+\mathrm{T}$ cell count and HIV viraemia at least) and a clinical examination before travelling. ${ }^{54}$ Obviously, for HIV-infected pregnant women and young children travel should be avoided if not strictly necessary as they have higher risks of severe malaria clinical manifestations.

Then, physicians involved in HIV care as well as in travel medicine should consider several factors in pretravel counselling for HIV-infected travellers such as reason for travel (tourism, VFR, business etc.), travel risk (pre-arranged or organized travel), travel destination, season and malarial epidemic cycle as well as Plasmodium drug sensitivity in the specific area; ${ }^{10}$ moreover HIV-infected people travelling to malaria endemic-areas need to start a correct chemoprophylaxis regimen before their travel and counsellors should consider possible drug interactions between antiretroviral and antimalarial drugs. ${ }^{10}$

Therefore the importance of behavioral preventive measures (bed nets, repellents, etc.), adequate chemoprophylaxis and, in selected circumstances, stand-by emergency treatment in case of evocative symptoms should be strongly recommended.

Effects of Co-Trimoxazole Prophylaxis and Antiretroviral Therapy on Malaria. According to major International Guidelines ${ }^{55,56}$ HAART regimens should contain at least three active drugs from two different classes, usually 2 nucleos(t)ide reverse transcriptase inhibitors (NRTIs) accompanied with an anchor drug which is either a non-nucleoside reverse transcriptase inhibitors (NNRTI) or a protease inhibitor (PI) with a low-dose of ritonavir (RTV) as "booster". Sustained virological suppression and CD4+ $\mathrm{T}$ cell count recovery is the main objective of HAART ${ }^{55}$ In HIV-infected patients, daily co-trimoxazole should to be prescribed as prophylaxis against major opportunistic infections when CD4+ T cells are less than $200 / \mu 1 ;{ }^{57}$ however several findings demonstrated that daily co-trimoxazole prescription may reduce the occurrence of parasitaemia ${ }^{58}$ and clinical malaria either in adults and in children. ${ }^{59,60,61}$

For example, Mermin $\mathrm{J}$ and colleagues ${ }^{58}$ found that among HIV-infected children the use of co-trimoxazole prophylaxis and insecticide-treated nets might reduce the prevalence of clinical malaria by $97 \%$ versus the reduction of $43 \%$ with nets alone. Therefore cotrimoxazole prescription in immunocompromised patients, in addition at insecticide-treated nets, seems to be an effective strategy to prevent malaria. However, cross resistance between co-trimoxazole and sulfadoxine-pyrimethamine (SP) has been reported, ${ }^{62}$ therefore widely use of co-trimoxazole may promote specific SP resistance; some studies did not find SP related resistances despite co-trimoxazole prescription, ${ }^{63,64}$ while others found that co-trimoxazole prophylaxis was effective despite antifolate resistance. $^{60}$

Therefore some authors suggested that a continuation of prophylaxis with co-trimoxazole in malaria endemic areas is beneficial even when patients have been immune restored. ${ }^{11}$ Antiretroviral therapy may be effective against malaria infection: Mermin J et $\mathrm{al}^{65}$ in a prospective cohort study found that HAART containing NRTIs when co-administrated with cotrimoxazole decrease malaria clinical presentation in 
respect of co-trimoxazole alone; in order to provide an explanation on the possible antimalarial activity of NRTIs, authors hypothesized that HAART probably reduced the frequency of malaria by improving immune function rather than by a direct antimalarial effect. A delayed P. falciparum clearance in HIVinfected patients treated with artemisinin-based regimens has been reported ${ }^{66}$ suggesting that immune defences of HIV-infected people may affect effectiveness of antimalarial treatment. Other studies evaluating impact of PIs are ongoing (e.g. NCT00719602) but available studies "in vitro" showed that the PIs lopinavir, saquinavir, indinavir, atazanavir ritonavir have direct effect on inhibition of $P$. falciparum, at concentration used in clinical practice. $^{67,68}$ Anyway, antiretroviral treatment maybe effective against $P$. falciparum and may reduce malarial clinical manifestation, but, in order to better clarify this hypothesis, its underlying biological mechanisms and the role of antiretroviral drugs or classes need further investigations.

\section{Interactions Between Antiretrovirals and Antimalarial Agents:}

Antiretrovirals and antimalarial drugs (treatment). Pharmacological interactions between antiretroviral and antimalarial drugs has been previously extensively reviewed, ${ }^{69,13}$ however the knowledge about this critical topic is still debated and data reported are not definitive, particularly due to either the paucity of data about newer drugs and classes of antiretroviral agents and the absence of specific guidelines. Moreover the relevance of "in vitro" studies in common clinical practice is controversial. According to WHO, first-line treatment for uncomplicated malaria in highendemicity areas consists of a combination of either artemether plus lumefantrine or artesunate plus one of the following drugs: amodiaquine, mefloquine, or sulfadoxine-pyrimethamine, or dihydroartemisininpiperaquine. ${ }^{1}$ Interactions between amodiaquine and efavirenz has been reported reflecting in higher amodiquine concentrations; ${ }^{70}$ these evidences may have a clinical impact, as a significant number of HIVinfected patients in sub-Saharan Africa receive an efavirenz-based treatment ${ }^{57}$ and WHO contraindicates this co-administration; ${ }^{27}$ furthermore, given that these drugs are both potentially hepatotoxic ${ }^{71,72}$ patients prescribing this combination have to be strictly monitored. Finally, we know that quinine, halofantrine, and lumefantrine are all antimalarial drugs metabolized through the cytochrome P-450 enzyme system; ${ }^{73,74}$ so that, these drugs may potentially interact with the nonnucleoside reverse transcriptase inhibitors (NNRTIs) resulting in reduced bioavailability of the antimalarial drugs. ${ }^{75}$ Recently, a cross-sectional study in HIV and malaria co-infected adults showed significant pharmacokinetic interactions among nevirapine, artemether and dihydroartemisinin: these interactions maybe increase the risk of treatment failure of both infections and the risk for development of drug resistance. ${ }^{76}$ Drug-interactions with PIs, that are also metabolized through the hepatic cytochrome P-450 enzyme system, and enzyme inhibition by ritonavir may on the contrary increase serum concentrations of these antimalarials. ${ }^{77}$ Despite this study, performed in healthy volunteers, ritonavir might boost the bioavailability of either PIs and antimalarial drugs, however this altered pharmacokinetics do not seems clinically relevant. By contrast, a recent study confirmed that LPV/r-based HAART significantly increases lumefantrine exposure without an increase in adverse effects. Artemether and dihydroartemisinin concentrations were also significantly increased by ritonavir boosted lopinavir-based treatment, but to a lesser extent. ${ }^{78}$ Data from randomized-controlled trials will be highly valuable in evaluating the clinical significance of all these interactions.

Most of potential clinically significant interactions between antimalarial and antiretrovirals drugs are showed in Table 1.

Malaria chemoprophylaxis in HIV infected subjects. Despite several reports and reviews on malaria and HIV co-infection, few data are present in literature about the use of malaria chemoprophylaxis in HIV infected travellers. ${ }^{57}$ Mefloquine reduces some ritonavir boosted protease inhibitors levels and mefloquine plasma levels could be reduced by efavirenz and nevirapine, but these data are from patients who received mefloquine as treatment, little is known about its use in chemoprophylactic regimen. Atovaquone/proguanil levels could be reduced by indinavir, as well as lopinavir, atazanavir, ritonavir and efavirenz; ${ }^{79}$ moreover, atovaquone/proguanil could reduce indinavir levels and increase zidovudine levels causing hematological troubles. ${ }^{80}$ No significant data are available on doxycycline interactions. ${ }^{81}$ All these considerations should be taken into account before starting chemoprophylaxis in HIV infected travelers taking HAART, and drugs dosages should be arranged in order to avoid drug interactions. If chemoprophylaxis is not administered, atovaquone/proguanil might be a suitable stand-by emergency treatment (SBET) option for HIV-infected subjects receiving NNRTI-based regimens, while mefloquine could be considered as SBET drug in those prescribing PI-based HAART. ${ }^{82}$

Conclusion And Future Research Perspectives. Malaria and HIV infections are two of the most 
Table 1: Potential interactions between antimalarial and antiretroviral drugs.

\begin{tabular}{|c|c|c|}
\hline Antimalarial drugs & Antiretroviral drugs & Potential interactions \\
\hline Quinine & EFV, NVP & Reduced quinine concentrations \\
\hline Quinine & PI & Reduced quinine concentrations \\
\hline Atovaquone/Proguanil & $\begin{array}{c}\mathrm{RTV}, \mathrm{LPV} / \mathrm{r}, \mathrm{ATV} / \mathrm{r}, \mathrm{IDV}, \\
\mathrm{EFV}\end{array}$ & Reduced atovaquone/proguanil concentrations \\
\hline Atovaquone/Proguanil & IDV & Reduced IDV concentrations \\
\hline Atovaquone/Proguanil & AZT & $\begin{array}{l}\text { Increased AZT concentrations } \\
\text { Increased risk for anaemia }\end{array}$ \\
\hline Mefloquine & RTV & Reduced RTV concentrations \\
\hline Mefloquine & EFV, NVP & Reduced mefloquine concentrations \\
\hline Lumefantrine & PI & $\begin{array}{l}\text { Increased lumefantrine concentrations } \\
\text { Prolongation of QT interval }\end{array}$ \\
\hline Lumefantrine & NVP, EFV, DLV & $\begin{array}{l}\text { Reduced lumefantrine concentrations } \\
\text { Prolongation of QT interval }\end{array}$ \\
\hline Halofantrine & PI & $\begin{array}{l}\text { Increased halofantrine concentrations } \\
\text { Prolongation of QT interval }\end{array}$ \\
\hline Halofantrine & NVP, EFV, DLV & $\begin{array}{l}\text { Reduced halofantrine concentrations } \\
\text { Prolongation of QT interval }\end{array}$ \\
\hline Amodiaquine + artesunate & $\mathrm{EFV}$ & $\begin{array}{l}\text { Increased amodiaquine concentrations } \\
\text { Increased transaminase levels }\end{array}$ \\
\hline Chloroquine & RTV & Alteration of antimalarial drug metabolism \\
\hline Pyrimethamine & RTV & Alteration of antimalarial drug metabolism \\
\hline Sulfadoxine-pyrimethamine & RTV & Alteration of antimalarial drug metabolism \\
\hline Sulfadoxine-pyrimethamine & NVP & Possible adverse cutaneous or hepatic reactions \\
\hline Sulfadoxine-pyrimethamine & AZT & Increased risk for anaemia \\
\hline Sulfadoxine-pyrimethamine & Co-trimoxazole & $\begin{array}{c}\text { Increased risk of severe adverse cutaneous or hepatic } \\
\text { reactions }\end{array}$ \\
\hline Artemisinin & PI & Alteration of artemisinin metabolism \\
\hline Dapsone & SQV & Alteration of dapsone metabolism \\
\hline
\end{tabular}

Modified by Flateau C, Lancet Infect Dis, 2011; Skinner-Adams TS, Trends Parasitol, 2008; Khoo S, AIDS, $2005 .{ }^{11,13,69}$

EFV: efavirenz; NVP: nevirapine; PI: protease inhibitors; RTV: ritonavir; LPV: lopinavir boosted by ritonavir; ATV/r: atazanavir boosted by ritonavir; IDV: indinavir; AZT: zidovudine; DLV: delavirdine; SQV: saquinavir.

important infectious diseases worldwide, particularly in sub-Saharan Africa: their overlapping epidemiology as well their impact in clinical practice needs to be continuously updated.

HIV-infected adults, especially if international travelers, even with a restored immunity, are more likely to have severe clinical manifestations of malaria compared to travellers without HIV infection. Moreover co-infection in pregnant women contributes to develop clinical malaria in women, maternal severe anaemia, grater rates of stillbirth and preterm delivery, low birth weight, foetal grow retardation and increased risk of infant mortality.

The wider implementation of co-trimoxazole prophylaxis and antiretroviral therapy could change the impact of malaria in HIV-infected patients.

The benefits of the continuation of co-trimoxazole prophylaxis to prevent malaria, the antimalarial effects of several antiretroviral agents, as well the interactions between antiretroviral and antimalarial drugs, need to be further investigated. The proper malaria prophylaxis and treatment in HIV-infected pregnant women also needs to be defined. Several clinical trials are ongoing to address several of these opened questions: the results of these trials are needed to create specific guidelines for the prevention and management of malaria and HIV co-infection and to help clinicians involved in travel medicine as well in HIV care.

Authors' Contributions. All authors conceived the concept and design of the review. EF, SO, and NB wrote and GC critically revised the review. All authors approved the final version for submission.

Conflict of Interest. EF and GC have received unrestricted educational grants (as speakers or for participation to conferences) from several Pharmaceuticals Companies producing antiretroviral drugs but this did not influence the content of this review. SO and NB declare no conflicts of interest. 


\section{References:}

1. WHO. Guidelines for the treatment of malaria, 2nd edition. Geneva, World Health Organization. 2010. http://whqlibdoc.who.int/publications/2010/9789241547925_eng.p df

2. WHO. World malaria report 2010. Geneva, World Health Organization, 2010. http://whqlibdoc.who.int/publications/2010/9789241564106_eng.p df

3. Palella FJ jr, Delaney KM, Moorman AC, Loveless MO, Fuhrer J, Satten GA, Aschman DJ, Holmberg SD. Declining morbidity and mortality among patients with advanced human immunodeficiency virus infection. HIV Outpatient Study Investigators. N Engl J Med. 1998; 338(13):853-60 http://dx.doi.org/10.1056/NEJM199803263381301 PMid:9516219

4. WHO. Global HIV/AIDS response: epidemic update and health sector progress towards universal access: progress report 2011. Geneva, World Health Organization, 2011. http://whqlibdoc.who.int/publications/2011/9789241502986 eng.p df

5. Abu-Raddad LJ, Patnaik P, Kublin JG. Dual infection with HIV and malaria fuels the spread of both diseases in sub-Saharan Africa. Science. 2006; 314(5805):1603-6 http://dx.doi.org/10.1126/science.1132338 PMid:17158329

6. Rana FS, Hawken MP, Mwachari C, Bhatt SM, Abdullah F, Ng'ang'a LW, Power C, Githui WA, Porter JD, Lucas SB. Autopsy study of HIV-1-positive and HIV-1-negative adult medical patients in Nairobi, Kenya. J Acquir Immune Defic Syndr. 2000; 24(1):239 PMid:10877491

7. Holmes CB, Losina E, Walensky RP, Yazdanpanah Y, Freedberg KA. Review of human immunodeficiency virus type 1-related opportunistic infections in sub-Saharan Africa. Clin Infect Dis. 2003; 36(5):652-62 $\quad$ http://dx.doi.org/10.1086/367655 PMid: 12594648

8. Steketee RW, Nahlen BL, Parise ME, Menendez C. The burden of malaria in pregnancy in malaria-endemic areas. Am J Trop Med Hyg. 2001; 64(1-2 suppl):28-35

9. Cohen C, Karstaedt A, Frean J, Thomas J, Govender N, Prentice E, Dini L, Galpin J, Crewe-Brown H. Increased prevalence of severe malaria in HIV-infected adults in South Africa. Clin Infect Dis. 2005; 41(11):1631-37 http://dx.doi.org/10.1086/498023 PMid:16267737

10. Bhadelia N, Klotman M, Caplivski D. The HIV-positive traveler. Am J Med. 2007; 120(7):574-80 http://dx.doi.org/10.1016/j.amjmed.2007.02.018 PMid:17602926

11. Flateau C, Le Loup G, Pialoux G. Consequences of HIV infection on malaria and therapeutic implications: a systematic review. $\begin{array}{llll}\text { Lancet Infect } & \text { Dis. } 2011 ; & 11(7): 541-56\end{array}$ http://dx.doi.org/10.1016/S1473-3099(11)70031-7

12. Idemyor V. Human immunodeficiency virus (HIV) and malaria interaction in sub-Saharan Africa: the collision of two Titans. HIV Clin Trials. 2007; 8(4):246-53 http://dx.doi.org/10.1310/hct0804246 PMid:17720665

13. Skinner-Adams TS, McCarthy JS, Gardiner DL, Andrews KT. HIV and malaria co-infection: interactions and consequences of chemotherapy. Trends Parasitol. 2008; 24(6):264-71 http://dx.doi.org/10.1016/j.pt.2008.03.008 PMid:18456554

14. Whitworth J, Morgan D, Quigley M, Smith A, Mayanja B, Eotu H, Omoding N, Okongo M, Malamba S, Ojwiya A. Effect of HIV-1 and increasing immunosuppression on malaria parasitaemia and clinical episodes in adults in rural Uganda: a cohort study. Lancet. 2000; 356(9235):1051-6 http://dx.doi.org/10.1016/S01406736(00)02727-6

15. Xiao L, Owen SM, Rudolph DL, Lal RB, Lal AA. Plasmodium falciparum antigen-induced human immunodeficiency virus type 1 replication is mediated through induction of tumor necrosis factor$\begin{array}{lllll}\text { alpha. J Infect } \quad \text { Dis. 1998; } & \text { 177):437-45 }\end{array}$ http://dx.doi.org/10.1086/514212 PMid:9466533

16. French N, Nakiyingi J, Lugada E, Watera C, Whitworth JA, Gilks $\mathrm{CF}$. Increasing rates of malarial fever with deteriorating immune status in HIV-1-infected Ugandan adults. AIDS. 2001; 15(7):899906 http://dx.doi.org/10.1097/00002030-200105040-00010 PMid:11399962
17. Patnaik P, Jere CS, Miller WC, Hoffman IF, Wirima J, Pendame R, Meshnick SR, Taylor TE, Molyneux ME, Kublin JG. Effects of HIV-1 serostatus, HIV-1 RNA concentration, and CD4 cell count on the incidence of malaria infection in a cohort of adults in rural $\begin{array}{llll}\text { Malawi. J Infect Dis. 2005; 192(6):984-91 } & \end{array}$ http://dx.doi.org/10.1086/432730 PMid:16107950

18. Grimwade K, French N, Mbatha DD, Zungu DD, Dedicoat M, Gilks CF. HIV infection as cofactor for severe falciparum malaria in adults living in a region of unstable malaria transmission in South Africa. AIDS. 2004; 18(3):547-554 http://dx.doi.org/10.1097/00002030-200402200-00023 PMid:15090809

19. Colebunders R, Karstaedt A, Frean J, Thomas J, Govender N, Prentice E, Dini L, Galpin J, Crewe-Brown H. Incidence of malaria and efficacy of oral quinine in patients recently infected with human immunodeficiency virus in Kinshasa, Zaire. J Infect. 1990; 21(2):167-73 http://dx.doi.org/10.1016/0163-4453(90)91701-E

20. Nguyen-Dinh P, Greenberg AE, Mann JM, Kabote N, Francis H, Colebunders RL, Huong AY, Quinn TC, Davachi F, Lyamba B, et al. Absence of association between Plasmodium falciparum malaria and human immunodeficiency virus infection in children in Kinshasa, Zaire. Bull World Health Organ. 1987; 65:607-13 PMid:3322600 PMCid:2491065

21. Diallo AH, Ki-Zerbo G, Sawadogo AB, Guiguemde TR. Severe malaria and HIV in adult patients in Bobo-Dioulasso, Burkina Faso. Med Trop. 2004; 64:345-50

22. Van Geertruyden JP, Mulenga M, Chalwe V, Michael N, Moerman F, Mukwamataba D, Colebunders R, D'alessandro U. Impact of HIV-1 infection on the hematological recovery after clinical malaria. J Acquir Immune Defic Syndr. 2009; 50(2):200-5 http://dx.doi.org/10.1097/QAI.0b013e3181900159 PMid:19131887

23. Brentlinger PE, Behrens CB, Kublin JG. Challenges in the prevention, diagnosis, and treatment of malaria in human immunodeficiency virus infected adults in sub-Saharan Africa. Arch Intern Med. 2007; 167(17):1827-36 http://dx.doi.org/10.1001/archinte.167.17.1827 PMid:17893303

24. Hoffman IF, Jere CS, Taylor TE, Munthali P, Dyer JR, Wirima JJ, Rogerson SJ, Kumwenda N, Eron JJ, Fiscus SA, Chakraborty H, Taha TE, Cohen MS, Molyneux ME. The effect of Plasmodium falciparum malaria on HIV-1 RNA blood plasma concentration. AIDS. 1999; 13(4):487-94 http://dx.doi.org/10.1097/00002030199903110-00007 PMid:10197377

25. Kublin JG, Patnaik P, Jere CS, Miller WC, Hoffman IF, Chimbiya N, Pendame R, Taylor TE, Molyneux ME. Effect of Plasmodium falciparum malaria on concentration of HIV-1-RNA in the blood of adults in rural Malawi: a prospective cohort study. Lancet. 2005; 365(9455):233-40PMid:15652606

26. Lee TH, Sakahara N, Fiebig E, Busch MP, O'Brien TR, Herman SA. Correlation of HIV-1 from RNA levels in plasma and heterosexual transmission of HIV-1 from infected transfusion recipients. J Acquir Immune Defic Syndr Hum Retrovirol. 1996; 12:427-428 http://dx.doi.org/10.1097/00042560-199608010-00015 PMid:8673554

27. WHO. Malaria and HIV/AIDS interactions and their implications for public health policy. Report of a technical consultation. 23-25 June 2004. Geneva, World Health Organization, 2004. http://www.who.int/hiv/pub/prev_care/malariahiv.pdf

28. Uneke CJ. Impact of placental Plasmodium falciparum malaria on pregnancy and perinatal outcome in sub-Saharan Africa: I: introduction to placental malaria. Yale J Biol Med. 2007; 80(2):3950 PMid:18160989 PMCid:2140183

29. Meeusen EN, Bischof RJ, Lee CS. Comparative T-cell responses during pregnancy in large animals and humans. Am J Reprod Immunol. 2001; 46(2):169-79 http://dx.doi.org/10.1111/i.87558920.2001.460208.x PMid:11506082

30. Ismail MR, Ordi J, Menendez C, Ventura PJ, Aponte JJ, Kahigwa E, Hirt R, Cardesa A, Alonso PL. Placental pathology in malaria: a histological, immunohistochemical, and quantitative study. Hum Pathol. 2000; 31(1):85-93 http://dx.doi.org/10.1016/S00468177(00)80203-8

31. Pell C, Straus L, Andrew EV, Meñaca A, Pool R. Social and 
cultural factors affecting uptake of interventions for malaria in pregnancy in Africa: a systematic review of the qualitative research. PLoS One. 2011; 6(7):e22452 http://dx.doi.org/10.1371/journal.pone.0022452 PMid:21799859 PMCid:3140529

32. Briand V, Badaut C, Cot M. Placental malaria, maternal HIV infection and infant morbidity. Ann Trop Paediatr. 2009; 29(2):7183. http://dx.doi.org/10.1179/146532809X440699 PMid:19460261

33. van Ejik AM, Ayisi JG, ter Kuile FO, Misore AO, Otieno JA, Rosen DH, Kager PA, Steketee RW, Nahlen BL. HIV increases the risk of malaria in women of all gravidities in Kisumu, Kenya. AIDS. 2003; 17(13):2002-2003 PMid:12960841

34. ter Kuile FO, Parise ME, Verhoeff FH, Udhayakumar V, Newman RD, van Eijk AM, Rogerson SJ, Steketee RW. The burden of coinfection with human immunodeficiency virus type 1 and malaria in pregnant women in sub-saharan Africa. Am J Trop Med Hyg. 2004; 71(2 Suppl):41-54 PMid:15331818

35. Ajisi JC, van Eijk AM, ter Kuile FO, Kolczak MS, Otieno JA, Misore AO, Kager PA, Steketee RW, Nahlen BL. The effect of dual infection with HIV and malaria on pregnancy outcome in western Kenya. AIDS. 2003; 17:585-94 http://dx.doi.org/10.1097/00002030-200303070-00014 PMid:12598779

36. Ticconi C, Mapfumo M, Dorrucci M, Naha N, Tarira E, Pietropolli A, Rezza G. Effect of maternal HIV and malaria infection on pregnancy and perinatal outcome in Zimbabwe. J Acquir Immune $\begin{array}{lll}\text { Defic } & \text { Syndr. 2003; } & \text { 34):289-94 }\end{array}$ http://dx.doi.org/10.1097/00126334-200311010-00005

37. Bloland PB, Wirima JJ, Steketee RW, Chilima B, Hightower A, Breman JG. Maternal HIV infection and infant mortality in Malawi: evidence for increased mortality due to placental malaria infection. $\quad$ AIDS. 1995; 9(7):721-6 http://dx.doi.org/10.1097/00002030-199507000-00009 PMid:7546417

38. Mwapasa V, Rogerson SJ, Molyneux ME, Abrams ET, Kamwendo DD, Lema VM, Tadesse E, Chaluluka E, Wilson PE, Meshnick SR. The effect of Plasmodium falciparum malaria on peripheral and placental HIV-1 RNA concentrations in pregnant Malawian women. AIDS. 2004; 18(7):1051-9 http://dx.doi.org/10.1097/00002030-200404300-00014 PMid:15096809

39. WHO. Antiretroviral drugs for treating pregnant women and preventing HIV infection in infants. Recommendations for a public health approach. Geneva, World Health Organization, 2010. http://whqlibdoc.who.int/publications/2010/9789241599818 eng.p $\underline{\mathrm{df}}$

40. United Nations World Tourism Organization (UNWTO), Tourism ighlights 2011 Edition. http://mkt.unwto.org/sites/all/files/docpdf/unwtohighlights11enlr 3 .pdf

41. Gautret P, Schlagenhauf P, Gaudart J, Castelli F, Brouqui P, von Sonnenburg F, Loutan L, Parola P; GeoSentinel Surveillance Network. Multicenter EuroTravNet/GeoSentinel study of travelrelated infectious diseases in Europe. Emerg Infect Dis. 2009; 15(11):1783-90 PMid:19891866 PMCid:2857260

42. Millet JP, Olalla PG, Gascón J, Prat JG, Trevino B, Pinazo MJ, Cabezos J, Munoz J, Zarzuela F, Caylà JA. Imported malaria among African immigrants: is there still a relationship between developed countries and their ex-colonies? Malar J. 2009; 8:111 PMid:19463171 PMCid:2693516

43. Kemper CA, Linett A, Kane C, Deresinsky SC. Frequency of travel of adults infected with HIV. J Travel Med 1995; 2(2):85-8 http://dx.doi.org/10.1111/j.1708-8305.1995.tb00632.x PMid:9815367

44. Sherrard AW, McCarthy AE. Travel patterns and health risks for patients infected with HIV. Travel Med Infect Dis. 2009; 7(5):2915 http://dx.doi.org/10.1016/j.tmaid.2009.03.006 PMid:19747664

45. Salit IE, Sano M, Boggild AK, Kain KC. Travel patterns and risk behaviour of HIV-positive people traveling internationally. CMAJ. 2005; 172(7):884-8 $\quad$ http://dx.doi.org/10.1503/cmaj.1040877 PMid:15795409 PMCid:554873

46. Chalwe V, Van geertruyden JP, Mukwamataba D, Menten J, Kamalamba J, Mulenga M, D'Alessandro U. Increased risk for severe malaria in HIV-1-infected adults, Zambia. Emerg Infect Dis. 2009; 15(5):749-55 http://dx.doi.org/10.3201/eid1505.081009
PMid:19402961 PMCid:2687012

47. Franco-Paredes C, Hidron A, Tellez I, Lesesne J, Del Rio C. HIV infection and travel: pretravel recommendations and health-related risks. Top HIV Med. 2009; 17(1):2-11 PMid:19270343

48. Castelli F, Odolini S, Autino B, Foca E, Russo R. Malaria prophylaxis: a comprehensive review. Pharmaceuticals. 2010; 3:3212-3239 http://dx.doi.org/10.3390/ph3103212

49. Mouala C, Houzé S, Guiguet M, Abboud P, Pialoux G, Viget N, Costagliola D, Matheron S. Imported malaria in HIV-infected patients enrolled in the ANRS CO4 FHDH study. J Acquir Immune $\begin{array}{lll}\text { Defic Syndr. } & \text { 2008; } & \text { 49):55-60 }\end{array}$ http://dx.doi.org/10.1097/QAI.0b013e31817e635b PMid:18667929

50. Mouala C, Guiguet M, Houzé S, Damond F, Pialoux G, Viget N, Costagliola D, Le Bras J, Matheron S; FHDH-ANRS CO4 Clinical Epidemiology Group. Impact of HIV infection on severity of imported malaria is restricted to patients with CD4 cell counts < 350 cells/microl. AIDS. 2009; 23(15):1997-2004 http://dx.doi.org/10.1097/QAD.0b013e32832f4215 PMid:19654499

51. Matteelli A, Casalini C, Bussi G, Saleri N, Nasta P, Pizzocolo C, Gulletta M, Castelli F. Imported malaria in an HIV-positive traveler: a case report with a fatal outcome. J Travel Med. 2005; 12(4):222-4 http://dx.doi.org/10.2310/7060.2005.12409

52. Zamidei L, Durval A, Bettocchi D, Luzzio MG, Bartoloni A, Consales G. Efficacy and safety of quinine-artesunate in an HIVpositive patient with severe falciparum malaria. Minerva Anestesiol. 2010 Jan;76(1):66-9 PMid:20125075

53. Ramírez-Olivencia G, Herrero MD, Subirats M, de Juanes JR, Peña JM, Puente S. Imported malaria and HIV infection in Madrid. Clinical and epidemiological features. Rev Clin Esp. 2012; 212(1):10-7 PMid:22071125

54. WHO. International travel and health: 2011. Geneva, World Health Organization, http://www.who.int/ith/chapters/ith2011chap7.pdf

55. Panel on Antiretroviral Guidelines for Adults and Adolescents. Guidelines for the use of antiretroviral agents in HIV-1-infected adults and adolescents. Department of Health and Human Services. October 14, 2011; 1-167. http://www.aidsinfo.nih.gov/ContentFiles/AdultandAdolescentGL. pdf

56. European AIDS Clinical Society (EACS). Guidelines. Version 6.1. November 2011. http://www.europeanaidsclinicalsociety.org/images/stories/EACSPdf/eacsguidelines-v6_english.pdf

57. WHO. Antiretroviral therapy for HIV infection in adults and adolescents, recommendations for a public health approach. Geneva, World Health Organization, 2010. http://whqlibdoc.who.int/publications/2010/9789241599764_eng.p df

58. Mermin J, Lule J, Ekwaru JP, Malamba S, Downing R, Ransom R, Kaharuza F, Culver D, Kizito F, Bunnell R, Kigozi A, Nakanjako D, Wafula W, Quick R. Effect of co-trimoxazole prophylaxis on morbidity, mortality, CD4-cell count, and viral load in HIV infection in rural Uganda. Lancet. 2004; 364(9443):1428-34 http://dx.doi.org/10.1016/S0140-6736(04)17225-5

59. Anglaret X, Chêne G, Attia A, Toure S, Lafont S, Combe P, Manlan K, N'Dri-Yoman T, Salamon R. Early chemoprophylaxis with trimethoprim-sulphamethoxazole for HIV-1-infected adults in Abidjan, Côte d'Ivoire: a randomised trial. Cotrimo-CI Study $\begin{array}{lll}\text { Group. } & \text { Lancet. } & \text { 1999; }\end{array}$ http://dx.doi.org/10.1016/S0140-6736(98)07399-1

60. Gasasira AF, Kamya MR, Ochong EO, Vora N, Achan J, Charlebois E, Ruel T, Kateera F, Meya DN, Havlir D, Rosenthal PJ, Dorsey G. Effect of trimethoprim-sulphamethoxazole on the risk of malaria in HIV-infected Ugandan children living in an area of widespread antifolate resistance. Malar J. 2010; 9:177 http://dx.doi.org/10.1186/1475-2875-9-177 PMid:20573194 PMCid:2903607

61. Kamya MR, Gasasira AF, Achan J, Mebrahtu T, Ruel T, Kekitiinwa A, Charlebois ED, Rosenthal PJ, Havlir D, Dorsey G. Effects of trimethoprim-sulfamethoxazole and insecticide-treated bednets on malaria among HIV-infected Ugandan children. AIDS. 2007; http://dx.doi.org/10.1097/QAD.0b013e3282ef6da1 
PMid:17885296

62. Iyer JK, Milhous WK, Cortese JF, Kublin JG, Plowe CV. Plasmodium falciparum cross-resistance between trimethoprim and $\begin{array}{lll}\text { pyrimethamine. } & \text { Lancet. 2001; 358(9287):1066-7 }\end{array}$ http://dx.doi.org/10.1016/S0140-6736(01)06201-8

63. Thera MA, Sehdev PS, Coulibaly D, Traore K, Garba MN, Cissoko Y, Kone A, Guindo A, Dicko A, Beavogui AH, Djimde AA, Lyke KE, Diallo DA, Doumbo OK,Plowe CV. Impact of trimethoprimsulfamethoxazole prophylaxis on falciparum malaria infection and disease. J Infect Dis. 2005; 192(10):1823-9 http://dx.doi.org/10.1086/498249 $\quad$ PMid:16235184 PMCid:2740817

64. Malamba S, Sandison T, Lule J, Reingold A, Walker J, Dorsey G, Mermin J. Plasmodium falciparum dihydrofolate reductase and dihyropteroate synthase mutations and the use of trimethoprimsulfamethoxazole prophylaxis among persons infected with human immunodeficiency virus. Am J Trop Med Hyg. 2010; 82(5):766-71 http://dx.doi.org/10.4269/ajtmh.2010.08-0408 PMid:20439953 PMCid:2861394

65. Mermin J, Ekwaru JP, Liechty CA, Were W, Downing R, Ransom R, Weidle P, Lule J, Coutinho A, Solberg P. Effect of cotrimoxazole prophylaxis, antiretroviral therapy, and insecticidetreated bednets on the frequency of malaria in HIV-1-infected adults in Uganda: a prospective cohort study. Lancet. 2006; 367(9518):1256-61 $\quad$ http://dx.doi.org/10.1016/S01406736(06)68541-3

66. Birku Y, Mekonnen E, Björkman A, Wolday D. Delayed clearance of Plasmodium falciparum in patients with human immunodeficiency virus co-infection treated with artemisinin. Ethiop Med J. 2002; 40 Suppl 1:17-26 PMid:12802828

67. Parikh S, Gut J, Istvan E, Goldberg DE, Havlir DV, Rosenthal PJ. Antimalarial activity of human immunodeficiency virus type 1 protease inhibitors. Antimicrob Agents Chemother. 2005; 49(7):2983-5 http://dx.doi.org/10.1128/AAC.49.7.2983-2985.2005 PMid:15980379 PMCid:1168637

68. Skinner-Adams TS, McCarthy JS, Gardiner DL, Hilton PM, Andrews KT. Antiretrovirals as antimalarial agents. J Infect Dis. 2004; 190(11):1998-2000 http://dx.doi.org/10.1086/425584 PMid:15529265

69. Khoo S, Back D, Winstanley P. The potential for interactions between antimalarial and antiretroviral drugs. AIDS. 2005; 19(10):995-1005 http://dx.doi.org/10.1097/01.aids.0000174445.40379.e0 PMid: 15958830

70. German P, Greenhouse B, Coates C, Dorsey G, Rosenthal PJ, Charlebois E, Lindegardh N, Havlir D, Aweeka FT. Hepatotoxicity due to a drug interaction between amodiaquine plus artesunate and efavirenz. Clin Infect Dis. 2007; 44(6):889-91 http://dx.doi.org/10.1086/511882 PMid:17304470

71. Guévart E, Aguémon A. Two cases of fulminant hepatitis during a curative treatment with an artesunate-amodiaquine combination. Med Mal Infect. 2009; 39(1):57-60 PMid:19013042
72. Martín-Carbonero L, Núñez M, González-Lahoz J, Soriano V. Incidence of liver injury after beginning antiretroviral therapy with efavirenz or nevirapine. HIV Clin Trials. 2003; 4(2):115-20 http://dx.doi.org/10.1310/N4VT-3E9U-4BKN-CRPW

73. Lefèvre G, Bindschedler M, Ezzet F, Schaeffer N, Meyer I, Thomsen MS. Pharmacokinetic interaction trial between coartemether and mefloquine. Eur J Pharm Sci. 2000; 10(2):141-51 http://dx.doi.org/10.1016/S0928-0987(00)00060-9

74. Svensson US, Ashton M. Identification of the human cytochrome P450 enzymes involved in the in vitro metabolism of artemisinin. $\mathrm{Br} J$ Clin Pharmacol. 1999; 48(4):528-35 http://dx.doi.org/10.1046/j.1365-2125.1999.00044.x PMCid:2014388

75. Plosker GL, Scott LJ. Saquinavir: a review of its use in boosted regimens for treating HIV infection. Drugs. 2003; 63(12):1299-324 http://dx.doi.org/10.2165/00003495-200363120-00007 PMid:12790697

76. Byakika-Kibwika P, Lamorde M, Mayanja-Kizza H, Katabira E, Khoo S, Back D, Lindegardh N, Tarning J, de Vries P, Merry C. Significant Pharmacokinetic Interaction between Nevirapine and Artemether-Lumefantrine in HIV+ Adults: Uganda. 19th Conference on Retroviruses and Opportunistic Infections, Seattle WA. 2012. p. 614

77. Khaliq Y, Gallicano K, Tisdale C, Carignan G, Cooper C, McCarthy A. Pharmacokinetic interaction between mefloquine and ritonavir in healthy volunteers. Br J Clin Pharmacol. 2001; 51(6):591-600 http://dx.doi.org/10.1046/j.1365-2125.2001.01393.x PMid:11422019 PMCid:2014486

78. Kredo T, Mauff K, van der Walt JS, Cohen K, Wiesner L, Smith P, Maartens G, Barnes K. The Interaction between Lopinavir/ritonavir and Artemether-Lumefantrine in HIV+ Patients. 19th Conference on Retroviruses and Opportunistic Infections, Seattle WA. 2012. p. 613

79. van Luin M, Van der Ende ME, Richter C, Visser M, Faraj D, Van der Ven A, Gelinck L, Kroon F, Wit FW, Van Schaik RH, Kuks PF, Burger DM. Lower atovaquone/proguanil concentrations in patients taking efavirenz, lopinavir/ritonavir or atazanavir/ritonavir. AIDS. 2010; 24(8):1223-6 http://dx.doi.org/10.1097/QAD.0b013e3283389129 PMid:20299957

80. Committee to advise on Tropical Medicine and travel (CATMAT). The immunocompromised traveller. An Advisory Committee Statement (ACS). Canada Communicable Dis. Rep. 2007; 33:1-24. http://origin.phac-aspc.gc.ca/publicat/ccdr-rmtc/07pdf/acs3304.pdf

81. University of Liverpool. Drug Interactions. http://www.hivdruginteractions.org/.

82. Cavassini ML, D'Acremont V, Furrer H, Genton B, Tarr PE. Pharmacotherapy, vaccines and malaria advice for HIV-infected travellers. Expert Opin Pharmacother. 2005; 6(6):891-913 http://dx.doi.org/10.1517/14656566.6.6.891 PMid:15952919 